\title{
Ocorrência de Crestamento Bacteriano do Gerânio, Causado por Xanthomonas hortorum pv. pelargonii, no Brasil
}

\author{
Valmir Duarte, Marisa Dalbosco \& Samira O. M. El Tassa \\ Departamento de Fitossanidade, Faculdade de Agronomia, UFRGS, Cx. Postal 15.100, CEP 90001-970, \\ Porto Alegre, RS, fax: (51) 3316-6016, e-mail: valmir@ufrgs.br
}

(Aceito para publicação em 19/10/2004)

Autor para correspondência: Valmir Duarte

\begin{abstract}
Occurrence of bacterial blight of geranium, caused by Xanthomonas hortorum pv. pelargonii, in Brazil This is the first report of bacterial blight of geranium (Pelargonium $\mathrm{x}$ hortorum), caused by Xanthomonas hortorum pv. pelargonii, in Brazil. The bacterium, isolated from geranium leaves showing wilt and blight, and growing in Nova Petrópolis, RS, was further identified by carbon source fingerprint (Biolog, Hayward, CA, USA) and pathogenicity test.
\end{abstract}

O Rio Grande do Sul tem-se mostrado um Estado promissor na produção de flores e plantas ornamentais, sendo o gerânio (Pelargonium x hortorum L. H. Bailey) uma das principais espécies produzidas. Plantas de gerânio, oriundas de Nova Petrópolis, RS, recebidas no Laboratório Oficial de Diagnóstico Fitossanitário da UFRGS, nos meses de julho e agosto de 2003, apresentavam murcha e crestamento foliar, caracterizado por manchas amarelas, marrons e necróticas, iniciando nos bordos do limbo foliar (Figura 1 A e B). A análise do material mostrou a presença de exsudação bacteriana a partir das lesões da folha. Colônias puras, mucóides, de coloração amarela pálido (Figura 1 C e D), contendo células gram e oxidase negativas, catalase positiva, foram obtidas em meio de cultura YDC (carbonato de cálcio, dextrose, extrato de levedura). A presença de xantomonadina foi detectada. Os testes de utilização de fontes de carbono (Biolog, Hayward, USA) indicaram que a bactéria utiliza glicose, manose, galactose, trealose, celobiose e frutose, características da espécie Xanthomonas campestris (Pammel 1895) Dowson 1939 (Krieg \& Holt, Bergey Manual of Systematic Bacteriology, 1984). O teste de patogenicidade, inoculando-se plantas de gerânio livres de sintomas, foi satisfeito. Assim, concluiu-se tratar-se de X. hortorum pv. pelargonii (Brown 1923) Vauterin, Hoste, Kerters \& Swings $1995=$ X. campestris pv. pelargonii (Brown 1923) Dye $1978 b$, agente causal do crestamento bacteriano do gerânio. Embora uma bactéria, causando podridão em gerânio no Estado de São Paulo, tenha sido identificada como Xanthomonas sp. (Sugimori et al., Summa Phytopathologica
13 (1/2):10. 1987), este é o primeiro relato de $X$. hortorum pv. pelargonii causando crestamento bacteriano em gerânio no Brasil. As estirpes encontram-se armazenadas no Laboratório de Fitobacteriologia, UFRGS, e no Instituto Biológico, SP, sob números 1974 e 1975.

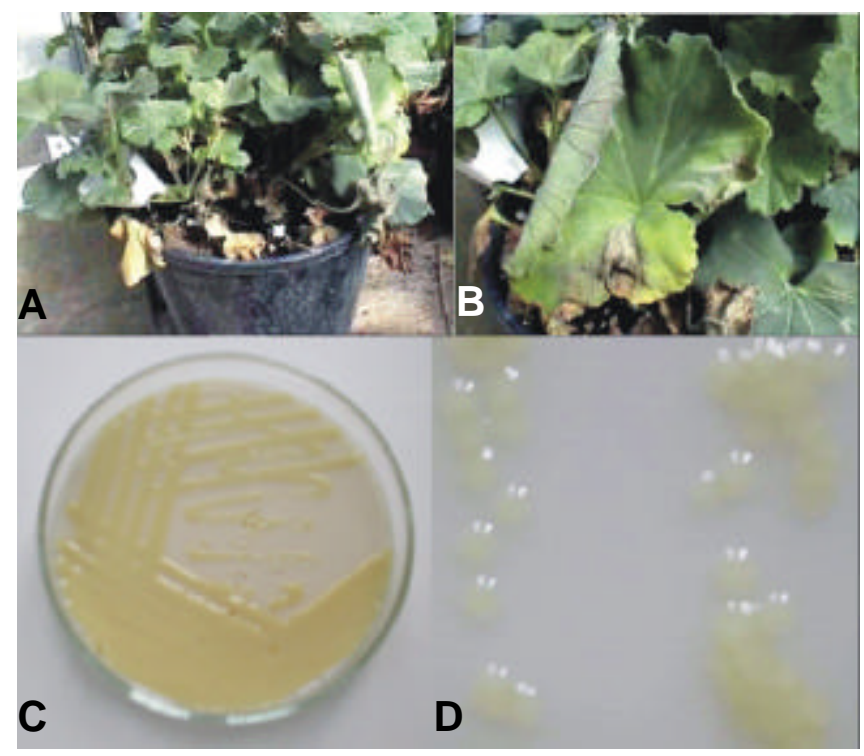

FIG. 1 - Sintomas de crestamento bacteriano em plantas de gerânio (Pelargonium x hortorum) (A e B); e cultura de Xanthomonas hortorum pv. pelargonii em meio YDC (C e D). Porto Alegre, 2003. 